\title{
A Case Study on the Development of Soft Skills among TESL Graduates in a University
}

\author{
Joanna Bunga Noah, Azlina Binti Abdul Aziz \\ Faculty of Education, Universiti Kebangsaan Malaysia, Malaysia
}

Received June 22, 2020; Revised August 1, 2020; Accepted August 25, 2020

\section{Cite This Paper in the following Citation Styles}

(a): [1] Joanna Bunga Noah, Azlina Binti Abdul Aziz, "A Case Study on the Development of Soft Skills among TESL Graduates in a University," Universal Journal of Educational Research, Vol. 8, No. 10, pp. 4610-4617, 2020. DOI: 10.13189/ujer.2020.081029.

(b): Joanna Bunga Noah, Azlina Binti Abdul Aziz (2020). A Case Study on the Development of Soft Skills among TESL Graduates in a University. Universal Journal of Educational Research, 8(10), 4610-4617. DOI: 10.13189/ujer.2020.081029.

Copyright $\odot 2020$ by authors, all rights reserved. Authors agree that this article remains permanently open access under the terms of the Creative Commons Attribution License 4.0 International License

\begin{abstract}
Graduates of higher education institutions (HEIs) should not only graduate with hard skills but also soft skills. Therefore, it is the responsibility of HEIs as platforms to provide sufficient holistic skills to their graduates so they may perform well at their future workplace. Despite that, graduates are still deemed lacking when it comes to soft skills. The same goes for trainee teachers, as having soft skills is a pertinent aspect as future educators, even for Teaching English as a Second Language (TESL) graduates. This paper aims to discuss the role of HEIs in developing soft skills of their TESL graduates. This study applied a mixed methodology via questionnaires and interviews to investigate the respondents' soft skills development which are, (a) critical thinking and problem-solving skills, (b) entrepreneurial skills and (c) moral and professional ethics based on their TESL program. The research findings showed that the respondents perceived the program generally to sufficiently develop their critical thinking and problem solving, entrepreneurship and moral and professional ethics skills as an outcome from the TESL program. However, improvements could be made to the TESL program in order to enhance their development of soft skills so to further improve the quality of teaching and learning and also aid employability. The findings are believed to be useful for future curriculum development of TESL programs in HEIs to consider the ongoing needs of stakeholders like schools when redesigning the curriculum of Teacher Education program.
\end{abstract}

Keywords Education, Soft Skills, TESL Program,
Trainee Teachers, University Graduates

\section{Introduction}

Governments should be able to gain economic success when they invest in the education of their citizens; this is according to the Human Capital Theory by Becker in 1975. Hence, the employability of graduates is crucial in order for governments to profit from their investment via said higher education [1,2]. Past research has proven that as individuals are better educated, the higher the chances of them having prestigious career options and are able to compete in the ever competitive global economy. Thus, the government's vision for implementation of soft skills in higher education institutions (HEIs) is in order to produce holistic graduates that would serve the nation in the future [3-5].

In Malaysia, it is still a challenge to produce graduates with a good set of soft skills that could aid employment [6,7]. According to the Malaysia's Education Blueprint 2015-2025 (Higher Education), "there is a mismatch in the supply and demand of graduates, with employers reporting that graduates lack the requisite knowledge, skills and attitudes" [8]. Graduates of HEIs should not only graduate with hard skills but also soft skills. Hard skills are the specific knowledge gained according to their discipline during the period of studies while soft skills comprise of the students' "people skills", which are not explicitly 
taught as an independent subject but are much needed for relational and personal advancement [9]. Both skills complement each other and are equally important in order to obtain a job and for career development.

Trainee teachers as like other graduates too, need the appropriate set of soft skills for employment in the education sector. Trainee teachers need to be equipped with soft skills for excellent and effective teaching practice [10]. This should be the responsibility of the HEIs to ensure that trainee teachers graduate not only with hard skills but also with the relevant soft skills $[11,12]$. However, HEIs are finding it difficult to develop this set of soft skills in the students. Lecturers have acknowledged the importance of soft skills integration in curriculum but have failed to integrate it in their pedagogy. This is due to some challenges, which include a huge classroom setting, time constrain and also students' awareness of the importance of soft skills development $[10,12,13]$.

In addition, based on a report in New Straits Times [14], the English language proficiency among students in Malaysian primary and secondary schools is still at an unsatisfactory level. This can be attributed to not only the lack of using English on a daily basis or students' lack of interest in acquiring English but can also be related back to the teachers' ability and competency to teach English as a second language in Malaysia. English teachers in Malaysian schools are none other than 'Teaching English as a Second Language' (TESL) graduates from various higher education institutions. Despite learning the theory and practical aspects of teaching English, soft skills development is also crucial in enabling trainee teachers to be confident and able to teach well once they graduate and move on to being teachers in real school settings.

Research on soft skills in Malaysia's HEIs especially on students' perception is still underway. Students' view is important as they are on the receiving end of the soft skills development. A wider perspective gained from students' insight can facilitate better choice of pedagogy to incorporate soft skills in the curricula [15]. Not only that, there is also a lack of research on soft skills teaching and learning methods especially for trainee teachers, which results in underdevelopment of soft skills among trainee teachers [13]. This study would like to address the research gap and focus on only three soft skills which are, (a) critical thinking and problem-solving skills, (b) entrepreneurial skills and (c) moral and professional ethics. These are derived from the Ministry of Higher Education's (MOHE) module of soft skills for HEIs from 2006. Consequently, this paper aims to discuss the role of HEIs in developing soft skills of their TESL graduates according to the curriculum of a Malaysian public university.

\section{Literature Review}

\subsection{Role of HEIs}

Higher education has evolved to be more accessible to everyone, which means more people are getting an education and that should lead to better job opportunities. This leads to the development of human capital, where through higher education it would enable people to have the appropriate set of skills according to different careers [16]. It is vital for HEIs to keep up with relevance of knowledge, identify skills gap and create new programmes that can cater to the ever-changing economic demands.

MOHE is always striving to provide the best education quality in line with governmental socioeconomic and development aspirations. One of the main goals of Malaysia's higher education system is to produce competitive graduates for the global market. However, Malaysia is still in need of graduates that have soft skills in order for the nation to achieve excellence [17]. Therefore, HEIs play a vital role in producing holistic graduates. Malaysian public universities are also working towards achieving the requirement of universities in producing knowledgeable and flexible graduates who have expertise in their discipline yet at the same time have excellent soft skills. In short, Malaysian public universities as HEIs are striving to not only equip students with hard skills according to discipline but also to equip them with adequate soft skills that would aid their employment and career progression.

\subsection{Soft Skills for TESL Trainee Teachers}

The goal of an education program should be to prepare the students for the education profession. Which is why hard skills are the main building block of the curriculum but soft skills should also be well integrated in order for the profession to be successful $[18,19]$. Students who undergo Bachelor of Education with Honours (Teaching English as a Second Language [TESL]) are indirectly trainee teachers as they are undergoing training in order to graduate to teach English as a Second Language in Malaysian secondary schools. Graduates of a TESL Program should be able to possess adequate soft skills that would enable them to be competent in the education sector or even any other sectors in the market. As with hard skills, soft skills can be gained through the TESL program. The development of professional knowledge and soft skills are best cultivated when theory evolves to practice. This can be achieved through programs, activities and also during the teaching practicum [20].

There are 7 skills outlined by MOHE, which are important for students to develop. The skills are communication skills in English, critical thinking and problem-solving skills, team-working skills, lifelong learning and information management skills, entrepreneurial skills, moral and professional ethics and leadership skills [21]. Although all skills are equally important for any profession, this research is only looking into three skills as would be discussed below.

\subsubsection{Critical Thinking and Problem Solving Skills}


Thinking skills is not foreign in the Malaysian school syllabus. The Ministry of Education (MOE) has implemented it in curricula since 1988 with the aim to produce human capital with higher thinking capacity [22]. In line with 21st Century Teaching and Learning that the MOE is heading towards, higher order thinking skills (HOTS) is given a lot of emphasis on. HOTS is not a stand-alone subject and should be a skill incorporated by teachers into their lessons, which is why teachers need to be competent in HOTS to be able to develop that particular skill among their students. HOTS is vital for both future teachers and students as it is relevant to knowledge-based economy and the development of information and communications technology (ICT) especially in this era of globalisation [22]. Which is why, critical thinking and problem solving skills is one of the important soft skills that a trainee teacher should be well developed with by the end of their undergraduate program. This is to enable trainee teachers to be able to identify and analyse situation as well as make justifiable decisions. It is also important for future teachers to have the ability to use their thinking skills in order to generate ideas and alternative solutions [12]. Other than trainee teachers having critical thinking and problem solving skills in order to integrate it in their lessons, this skill is also needed for teachers to use in learning management for children, which could help them better manage their classroom presence [23]. Thus far it can be seen that critical thinking and problem solving skills is pertinent to an educator.

\subsubsection{Entrepreneurial Skills}

Due to unemployment rates on the rise, entrepreneurship courses are more significant in HEIs, which leads to a more serious relationship between education and entrepreneurship, two things that used to not be connected. Entrepreneurship is defined as an individual's ability to turn an idea into a business practice. This means that the individual has the ability to build on an opportunity or solve a problem by creating a solution [24]. This is why entrepreneurship and education can go hand in hand as education could provide the skills needed for a student to be an entrepreneur. Trainee teachers in most public universities are not bonded with the MOE, which means after graduation they have a choice to apply to teach in any institutions. It also means that trainee teachers need not necessarily pursue a career in education. This is where entrepreneurial skills delivered by HEIs can help these graduates to venture out of teaching and are employable enough to pursue other careers [25]. Additionally, entrepreneurship is the transfer of ideas and knowledge into new situations. It also rides on one's creative and innovative mind and to build up a generation that is able to take risks and adapt to changes, these are skills, which are important to have in life $[12,24,26,27]$. Other than that, entrepreneurship can equip students with insights to analyse their environment in a more organised pattern and expose them to effective development and management at any level [27]. This means that entrepreneurship skills need to begin from trainee teachers, not only as a skill to instil in their future students but also as a personal life skill that could also enhance their teaching quality and career [26]. This is where entrepreneurship and education merges together. However, entrepreneurship, either as a stand-alone subject or integrated in pedagogy, is not common. There is also the mindset among trainee teachers that do not understand entrepreneurship beyond it being a business. Therefore, for the benefits entrepreneurship skills carry, it should be given emphasis among trainee teachers.

\subsubsection{Moral and Professional Ethics}

Moral and professional ethics should not be overlooked as an important soft skill to be acquired by trainee teachers. This skill is in line with thinking skills, as one needs to be able to analyse and make decisions that are right morally and ethically. Being morally and professionally ethical also means teachers do not practice favouritism among their students. Other than that, having good ethics gives one a sense of responsibility towards the society $[12,28,29]$. More importantly, teachers are role models to their students, as they interact with students on a daily basis. Students acquire knowledge and experiences via relations with mentors, in this case their teachers [29], which means that if teachers do not practice moral and professional ethics, it'll be difficult for their students to look up to someone. The challenge of developing moral and professional ethics can be more daunting as this skill does not have a measurable element and varies tremendously between individuals according to background [28]. It is therefore vital for trainee teachers to develop moral and professional ethics skill before entering the working world.

\section{Methodology}

This research used a mixed-method approach in order to gather both quantitative and qualitative data from different sources. The quantitative instrument used was questionnaires and interviews were carried out to collect qualitative data. This research is focused on final year TESL students because they could provide feedback on how the programme as a whole has developed their soft skills. It was important to include the final year students considering the other TESL batches have not completed all the courses in the programme and so their responses would be limited. Therefore, the study was conducted among Year 4 TESL students, consisting of only 36 students from a public university in Selangor, Malaysia. The questionnaire items were designed in order to find out the development of soft skills in students, some items were adapted from Hadiyanto [30], Orji [31] and Ismail et al. [32]. A pilot study was carried out and the Alpha-Cronbach value obtained was 0.911 . The questionnaire consisted of 24 items and was placed on a 5-point Likert scale (1="strongly disagree", $2=$ ="disagree", $3=$ ="neutral", 
4="agree", 5="strongly agree"). The return rate of the questionnaires was $100 \%$. The data was hen analysed via descriptive statistics. In order to further supplement the quantitative data, individual semi-structured interviews were carried out to 7 respondents. In order to conclude this study, all data gathered have been triangulated. This further strengthens the study through multiple methods of data collection and analysis.

\section{Findings \& Discussion}

5 males and 31 females, totaling to 36 Year 4 TESL students, answered the questionnaire of this research. 7 from those respondents were interviewed. The findings of this research will be discussed according to the development of the three skills: critical thinking and problem solving, entrepreneurial and moral and professional ethics.

\subsection{Development of Critical Thinking \& Problem Solving Skills}

Based on Table 1, it can be seen that the trainee teachers have generally developed critical thinking and problem solving skills as an outcome from the TESL program. According to item 5, 91.6\% $(\mathrm{n}=33)$ of the respondents are able to identify problems and from item $9,86.2 \%(n=31)$ are able to analyse problems from different perspectives. They are also able to come up with solutions, be creative and also solve a problem through several ways. The development of critical thinking and problem solving skills are evident, as according to the interviews, the respondents have mentioned that it has been integrated in the TESL program. Respondent B stated "I think the activity that has helped me would be the mentoring program from "Teaching of Writing Skills in an ESL Context" subject, where I needed to come up with suitable activities for my two mentees according to their level of proficiency in the English language." This clearly shows that as the trainee teacher was presented a problem, she managed to solve it by critically thinking about the solution while taking into account the level of proficiency she needed to tackle.

The development of critical thinking and problem solving has also helped the respondents in facing their classroom during their practical stint as English teachers. According to respondent $\mathrm{A}$, she said "I can think of a backup plan if my lesson delivery doesn't go as planned." The results coincide with a previous research by Ngang et al. [12], in which critical thinking and problem solving skills is essential for teachers who need to be quick to think and come up with solutions on the go. Other than that, this skill is also needed for teachers to use for classroom management and also to cater to the emotional needs of their students $[18,23]$.

In addition, from the interviews, the trainee teachers also believe the importance for them to cultivate critical thinking and problem solving skills in their students. This is in line with the MOE's implementation of HOTS in the 21 st century teaching and learning syllabus, which means that teachers need to be competent in this skill set. This is also supported by a previous study, $\mathrm{Wu}$ [33] stated that cultivating critical thinking and problem solving skills in students is an obligatory duty of educators yet is paid insufficient attention to. In the same research, Wu expresses that English teachers should not only focus on listening, speaking, reading and writing, but also train and guide students' thinking ability. Once again, the development of critical thinking and problem solving skills is important for trainee teachers to develop while undergoing their TESL program, not only for their own benefit but to inculcate it in their students and lessons as well.

Table 1. Development of Critical Thinking \& Problem Solving Skills

\begin{tabular}{|c|c|c|c|c|c|c|}
\hline No. & Items & $\begin{array}{l}\text { SD \% } \\
(\mathbf{N})\end{array}$ & $\begin{array}{l}\text { D \% } \\
(\mathrm{N})\end{array}$ & $\begin{array}{c}\mathbf{N} \% \\
(\mathbf{N})\end{array}$ & $\begin{array}{c}\mathbf{A} \% \\
(\mathbf{N})\end{array}$ & $\begin{array}{c}\text { SA \% } \\
(\mathbf{N})\end{array}$ \\
\hline 1 & I try to think out of the box when I write my assignments & 0 & 0 & $\begin{array}{c}11.1 \\
(4)\end{array}$ & $\begin{array}{l}69.4 \\
(25)\end{array}$ & $\begin{array}{c}19.4 \\
(7)\end{array}$ \\
\hline 2 & $\begin{array}{l}\text { I figure out how to complete an assignment by relating it to } \\
\text { previous tasks }\end{array}$ & 0 & 0 & $\begin{array}{l}5.6 \\
(2)\end{array}$ & $\begin{array}{l}55.6 \\
(20)\end{array}$ & $\begin{array}{l}38.9 \\
(14)\end{array}$ \\
\hline 3 & $\begin{array}{l}\text { I discuss ideas I have gained from class with my classmates outside } \\
\text { of class }\end{array}$ & 0 & $\begin{array}{l}8.3 \\
(3)\end{array}$ & $\begin{array}{l}16.7 \\
(6)\end{array}$ & $\begin{array}{l}44.4 \\
(16)\end{array}$ & $\begin{array}{l}30.6 \\
(11)\end{array}$ \\
\hline 4 & I answer questions using knowledge I have gained from class & 0 & 0 & $\begin{array}{l}5.6 \\
(2)\end{array}$ & $\begin{array}{l}55.6 \\
(20)\end{array}$ & $\begin{array}{l}38.9 \\
(14)\end{array}$ \\
\hline 5 & I can identify problems & 0 & 0 & $\begin{array}{l}8.3 \\
(3)\end{array}$ & $\begin{array}{l}72.2 \\
(26)\end{array}$ & $\begin{array}{l}19.4 \\
(7)\end{array}$ \\
\hline 6 & I can come up with solutions to problems & 0 & $\begin{array}{l}2.8 \\
(1) \\
\end{array}$ & $\begin{array}{c}11.1 \\
(4)\end{array}$ & $\begin{array}{l}66.7 \\
(24) \\
\end{array}$ & $\begin{array}{c}19.4 \\
(7)\end{array}$ \\
\hline 7 & I can be creative when solving problems & $\begin{array}{l}2.8 \\
(1)\end{array}$ & 0 & $\begin{array}{l}25 \\
(9)\end{array}$ & $\begin{array}{l}52.8 \\
(19)\end{array}$ & $\begin{array}{l}19.4 \\
(7)\end{array}$ \\
\hline 8 & I can come up with several ways to solve a problem & $\begin{array}{l}2.8 \\
(1)\end{array}$ & 0 & $\begin{array}{l}5.6 \\
(2)\end{array}$ & $\begin{array}{l}66.7 \\
(24)\end{array}$ & $\begin{array}{l}25 \\
(9)\end{array}$ \\
\hline 9 & I analyse a problem by looking at it from different perspectives & $\begin{array}{l}2.8 \\
(1)\end{array}$ & $\begin{array}{l}2.8 \\
(1) \\
\end{array}$ & $\begin{array}{l}8.3 \\
(3)\end{array}$ & $\begin{array}{l}55.6 \\
(20)\end{array}$ & $\begin{array}{l}30.6 \\
(11)\end{array}$ \\
\hline 10 & $\begin{array}{l}\text { The critical thinking and problem solving skills I have developed } \\
\text { would be help me in my future career }\end{array}$ & 0 & 0 & $\begin{array}{l}2.8 \\
(1)\end{array}$ & $\begin{array}{l}58.3 \\
(21)\end{array}$ & $\begin{array}{l}38.9 \\
(14)\end{array}$ \\
\hline
\end{tabular}

SD- Strongly Disagree, D- Disagree, N- Neutral, A- Agree, SA- Strongly Agree 
Table 2. Development of Entrepreneurial Skills

\begin{tabular}{|c|c|c|c|c|c|c|}
\hline No. & Items & $\begin{array}{c}\text { SD \% } \\
(\mathrm{N})\end{array}$ & $\begin{array}{l}\text { D \% } \\
(\mathrm{N})\end{array}$ & $\begin{array}{l}\mathbf{N} \% \\
(\mathrm{~N})\end{array}$ & $\begin{array}{c}\text { A \% } \\
(\mathrm{N})\end{array}$ & $\begin{array}{c}\text { SA \% } \\
\text { (N) }\end{array}$ \\
\hline 11 & I am able to think of a solution that could generate income & $\begin{array}{l}2.8 \\
(1)\end{array}$ & $\begin{array}{l}5.6 \\
(2)\end{array}$ & $\begin{array}{l}44.4 \\
(16)\end{array}$ & $\begin{array}{l}38.9 \\
(14)\end{array}$ & $\begin{array}{l}8.3 \\
(3)\end{array}$ \\
\hline 12 & I have ideas that can turn into business & $\begin{array}{l}5.6 \\
(2)\end{array}$ & $\begin{array}{c}16.7 \\
(6)\end{array}$ & $\begin{array}{l}30.6 \\
(11)\end{array}$ & $\begin{array}{l}36.1 \\
(13)\end{array}$ & $\begin{array}{l}11.1 \\
\text { (4) }\end{array}$ \\
\hline 13 & I can come up with a creative idea in new situations & $\begin{array}{l}2.8 \\
(1) \\
\end{array}$ & $\begin{array}{l}5.6 \\
(2)\end{array}$ & $\begin{array}{c}22.2 \\
(8)\end{array}$ & $\begin{array}{l}52.8 \\
(19) \\
\end{array}$ & $\begin{array}{c}16.7 \\
(6)\end{array}$ \\
\hline 14 & I am more self reliant and independent & 0 & 0 & $\begin{array}{c}22.2 \\
(8)\end{array}$ & $\begin{array}{l}44.4 \\
(16)\end{array}$ & $\begin{array}{l}33.3 \\
(12)\end{array}$ \\
\hline 15 & I understand risk management & 0 & $\begin{array}{l}5.6 \\
(2)\end{array}$ & $\begin{array}{l}25 \\
(9)\end{array}$ & $\begin{array}{c}50 \\
(18)\end{array}$ & $\begin{array}{c}19.4 \\
(7)\end{array}$ \\
\hline 16 & $\begin{array}{l}\text { I had a chance to participate in trade business through some } \\
\text { activities }\end{array}$ & $\begin{array}{l}8.3 \\
(3)\end{array}$ & $\begin{array}{l}25 \\
(9)\end{array}$ & $\begin{array}{l}36.1 \\
(13)\end{array}$ & $\begin{array}{c}19.4 \\
(7)\end{array}$ & $\begin{array}{c}11.1 \\
(4)\end{array}$ \\
\hline 17 & $\begin{array}{l}\text { The entrepreneurship skills I have developed would be help } \\
\text { me in my future career }\end{array}$ & $\begin{array}{l}2.8 \\
(1)\end{array}$ & $\begin{array}{c}11.1 \\
(4)\end{array}$ & $\begin{array}{l}33.3 \\
(12)\end{array}$ & $\begin{array}{l}41.7 \\
(15)\end{array}$ & $\begin{array}{c}11.1 \\
(4)\end{array}$ \\
\hline
\end{tabular}

SD- Strongly Disagree, D- Disagree, N- Neutral, A- Agree, SA- Strongly Agree

\subsection{Development of Entrepreneurial Skills}

Entrepreneurship courses are not the main focus of the TESL program, thus according to item 16 from table 2, $33.3 \%(n=12)$ of the respondents disagreed that they had a chance to participate in trade business through some activities. This datum is understandable due to the lack of entrepreneurship as part of the TESL program. However, according to item $13,69.5 \%(n=25)$ agreed that they can come up with a creative idea in new situations, from item $14,77.7 \%(\mathrm{n}=28)$ agreed that they are more self-reliant and independent and based on item 15, 69.4\% $(n=25)$ agreed that they understand risk management. The contradicting data are possible since the fundamentals of TESL do not have entrepreneurial elements in it thus trainee teachers rarely associate TESL with entrepreneurship together. However, entrepreneurship has been integrated into the TESL program via subjects like Entrepreneurship Education Fieldwork and through some class activities, like dramatisation. Respondent $\mathrm{C}$ mentioned that for the subject "Assessment in ELT", "the lecturer did not only teach us how to prepare questions that involve the Bloom's Taxonomy, she also guided us to produce a worksheet that can be commercialised. I personally find that I can use my expertise in the education field to produce my own exercise book." This is an example of an integration of entrepreneurship in a non-entrepreneurship course whereby the lecturer guides the students to be entrepreneurial and generates income avenues while still being in the education element. This shows that entrepreneurship skills are able to generate beneficial sub-skills, and for that, it should be given more priority in the TESL program.

According to Deveci [24], entrepreneurship skills develop the creativity of an individual and allow the individual to take risks and be independent. Based on an interview with respondent $\mathrm{C}$, she managed to generate some income through creativity, “...I was able to make money through one of the soft skills I acquired." Therefore, entrepreneurship skills, currently underdeveloped in the TESL program should be given a chance for the betterment of the TESL graduates. This is also significant as the TESL program is an open market course, which means TESL graduates need not be teachers and should be equipped with skills to be able to generate their own income. Especially with unemployment rates going up globally, having a definite skill set should enable graduates to still be able to survive any upcoming difficulties, like exploring business plans that could lead to self-employment $[12,24,27]$. The development of entrepreneurship skills also goes together with the development of critical thinking and problem solving skills as the individual builds on an opportunity or solve a problem by creating a solution, which is the business product [24]. Therefore, the development of entrepreneurship skills is important even if at the end of the day these trainee teachers do not go into business. 
Table 3. Development of Moral and Professional Ethics

\begin{tabular}{|c|c|c|c|c|c|c|}
\hline No. & Items & $\begin{array}{c}\mathrm{SD} \% \\
(\mathrm{~N})\end{array}$ & $\begin{array}{l}\mathrm{D} \% \\
(\mathrm{~N})\end{array}$ & $\begin{array}{l}\mathrm{N} \% \\
(\mathrm{~N})\end{array}$ & $\begin{array}{c}\text { A \% } \\
(\mathrm{N})\end{array}$ & $\begin{array}{c}\text { SA \% } \\
(\mathrm{N})\end{array}$ \\
\hline 18 & I am responsible to get my task done & 0 & 0 & $\begin{array}{l}2.8 \\
(1)\end{array}$ & $\begin{array}{l}30.6 \\
(11)\end{array}$ & $\begin{array}{l}66.7 \\
(24)\end{array}$ \\
\hline 19 & I practice integrity in my work & 0 & 0 & $\begin{array}{l}5.6 \\
(2)\end{array}$ & $\begin{array}{l}36.1 \\
(13)\end{array}$ & $\begin{array}{l}58.3 \\
(21)\end{array}$ \\
\hline 20 & I do not practice bias & 0 & 0 & $\begin{array}{l}2.8 \\
(1)\end{array}$ & $\begin{array}{l}38.9 \\
(14)\end{array}$ & $\begin{array}{l}58.3 \\
(21)\end{array}$ \\
\hline 21 & I am usually punctual & 0 & $\begin{array}{l}8.3 \\
(3) \\
\end{array}$ & $\begin{array}{l}8.3 \\
(3) \\
\end{array}$ & $\begin{array}{l}33.3 \\
(12) \\
\end{array}$ & $\begin{array}{c}50 \\
(18) \\
\end{array}$ \\
\hline 22 & I adhere to the university's dress code & 0 & $\begin{array}{c}13.9 \\
(5)\end{array}$ & $\begin{array}{c}22.2 \\
(8)\end{array}$ & $\begin{array}{l}33.3 \\
(12)\end{array}$ & $\begin{array}{l}30.6 \\
(11)\end{array}$ \\
\hline 23 & $\begin{array}{l}\text { I obey protocol whenever I attend an official } \\
\text { ceremony }\end{array}$ & 0 & 0 & $\begin{array}{l}8.3 \\
(3) \\
\end{array}$ & $\begin{array}{l}33.3 \\
(12) \\
\end{array}$ & $\begin{array}{l}58.3 \\
(21)\end{array}$ \\
\hline 24 & $\begin{array}{l}\text { The moral and professional ethics I have developed } \\
\text { would be help me in my future career }\end{array}$ & 0 & 0 & $\begin{array}{l}2.8 \\
(1)\end{array}$ & $\begin{array}{l}30.6 \\
(11)\end{array}$ & $\begin{array}{l}66.7 \\
(24)\end{array}$ \\
\hline
\end{tabular}

SD- Strongly Disagree, D- Disagree, N- Neutral, A- Agree, SA- Strongly Agree

\subsection{Development of Moral and Professional Ethics}

Findings from table 3 show that the respondents have also developed moral and professional ethics. Item 21 shows $83.3 \%(n=30)$ of the respondents agreed that they are usually punctual, from item $22,63.9 \%(\mathrm{n}=23)$ agreed that they adhere to the university's dress code and from item $23,91.6 \%(n=33)$ agreed that they obey protocol whenever they attend an official ceremony. Respondent $\mathrm{C}$ mentioned that "teaching requires a set of professionalism where it includes the way you present yourself, your choice of attire, your words, your content and much more. Therefore, studying at the Faculty of Education has moulded such attitude and professional upbringing. We were asked to dress like a real educator as a practice. It definitely prepared us to be conscious of our role in the society." This is supported by previous study from Ngang et al. [12] whereby it was agreed by their respondents that through dress code ethics and co-curricular activities, it helped developed their ethics and professionalism. Based on the interviews conducted, all the respondents agreed that moral and professional ethics is a beneficial skill to be used in their future career. It is also a skill that the respondents wish to be further integrated into the TESL program and a skill that is perceived to be needed by their future employers. Therefore, it is the responsibility of HEIs to instil moral and professional ethics in the students prior to them graduating and entering the workforce [34].

As teachers, it is important to have moral and professional ethics, some of which are being responsible, not practising bias and being punctual [28]. This is because teachers have the duty beyond teaching a particular subject, and to shape students into being morally and ethically right [29]. This skill is also in line with thinking skills, as one needs to be able to analyse and make decisions that are right morally and ethically. Respondent $\mathrm{D}$ finds that "teachers have a major role in every decision making in the classroom, so it's important for teachers to have a good attitude and ethics." This is true because teachers are decision makers most of the times, thus they need to display professionalism in this matter. Being morally and professionally ethical also means teachers do not practice favouritism among their students. Here, the importance of developing moral and professional ethics in teacher education can be seen which extends to TESL trainee teachers as well. Other than that, having good ethics gives one a sense of responsibility towards the society $[12,28,29]$. In short, moral and professional ethics is often overlooked as a soft skill and is not taught as a stand-alone subject but is equally important for trainee teachers to develop.

\section{Conclusions}

The development of soft skills among trainee teachers is evident in the TESL program. As the main focus of trainee teachers undergoing formal education is to prepare them for classroom-based knowledge, it is equally important for the trainee teachers to develop soft skills in order for them to be able to perform professional roles at school levels and beyond [35]. This is also in line with HEIs aim to produce high quality human capitals that are competent and prepared for the vast job market. The development of soft skills among trainee teachers is notable and helpful as future educators but it could also be improved drastically by revamping the TESL program. Therefore, it is the HEI's role to equip their students not only with discipline-related hard skills, but relevant soft skills needed for their future career.

\section{Acknowledgments}

The authors would like to express gratitude as this work was supported by Research Grant GG-2019-072 from Dana Penyelidikan FPEND, Universiti Kebangsaan Malaysia. 


\section{REFERENCES}

[1] Kennedy, A. (2015). What do professional learning policies say about purposes of teacher education?. Asia-Pacific journal of teacher education, 43(3), 183-194.

[2] Knight, P. T., \& Yorke, M. (2002). Employability through the curriculum. Tertiary education and management, 8(4), 261-276.

[3] Ahmad, M., Badusah, J., Mansor, A. Z., Abdul Karim, A., Khalid, F., Daud, M. Y., ... \& Zulkefle, D. F. (2016). The Application of 21st Century ICT Literacy Model among Teacher Trainees. Turkish Online Journal of Educational Technology-TOJET, 15(3), 151-161.

[4] Husain, H., Arsad, N., Bais, B., \& Kamal, N. (2016). Self-regulated learning in UKM. Pertanika Journal of Social Sciences and Humanities, 24(April), 77-86.

[5] Yunus, N. M., \& Said, R. (2016). Do higher levels of qualification lead to higher returns to education: Evidence from Malaysian education sector. International Journal of Economics and Financial Issues, 6(S6), 20-26.

[6] Idris, R., Ariffin, S. R., \& Ishak, N. M. (2019). Pengaruh kemahiran generik dalam kemahiran pemikiran kritikal, penyelesaian masalah dan komunikasi pelajar Universiti Kebangsaan Malaysia (UKM). Malaysian Journal of Learning and Instruction, 6, 103-140.

[7] Noah, J. B., \& Aziz, A. A. (2020). A Systematic review on soft skills development among university graduates. EDUCATUM Journal of Social Sciences, 6(1), 43-58.

[8] MOE, M. (2015). Malaysia Education Blueprint 2015-2025 (Higher Education). Kuala Lumpur: Ministry of Education Malaysia.

[9] Shakir, R. (2009). Soft skills at the Malaysian institutes of higher learning. Asia Pacific Education Review, 10(3), 309-315.

[10] Tang, K. N. (2018). The importance of soft skills acquisition by teachers in higher education institutions. Kasetsart Journal of Social Sciences.

[11] Häkkinen, P., Järvelä, S., Mäkitalo-Siegl, K., Ahonen, A., Näykki, P., \& Valtonen, T. (2017). Preparing teacher-students for twenty-first-century learning practices (PREP 21): a framework for enhancing collaborative problem-solving and strategic learning skills. Teachers and Teaching, 23(1), 25-41.

[12] Ngang, T. K., Yunus, H. M., \& Hashim, N. H. (2015). Soft skills integration in teaching professional training: Novice teachers' perspectives. Procedia-social and behavioral sciences, $186,835-840$.

[13] Hassan, A., Maharoff, M., Abiddin, N. Z., \& Ro'is, I. (2015). Teacher trainers' and trainee teachers' understanding towards the curriculum philosophy regarding soft skills embedment in the Malaysian Institute of Teacher Education. Policy Futures in Education, 14(2), 164-175.

[14] Sani, R. (2019, September 11). Addressing the challenges in teaching English: New Straits Times. Retrieved from https://www.nst.com.my/education/2019/09/520502/addres sing-challenges-teaching-english
[15] Nikitina, L., \& Furuoka, F. (2012). Sharp focus on soft skills: a case study of Malaysian university students' educational expectations. Educational Research for Policy and Practice, $11(3), 207-224$.

[16] Gibbs, L., \& Slevitch, L. (2019). Beyond the classroom: student employability and intention to stay in the hospitality industry. Journal of Teaching in Travel \& Tourism, 19(4), 267-284.

[17] Zain, N. M., Aspah, V., Abdullah, N., \& Ebrahimi, M. (2017). Challenges and evolution of higher education in Malaysia. UMRAN-International Journal of Islamic and Civilizational Studies, 4(1-1).

[18] Tsaoussi, A. I. (2020). Using soft skills courses to inspire law teachers: a new methodology for a more humanistic legal education. The Law Teacher, 54(1), 1-30.

[19] Pachauri, D., \& Yadav, A. (2014). Importance of soft skills in teacher education programme. International Journal of Educational Research and Technology, 5(1), 22-25.

[20] Yunus, M. M., Hashim, H., Ishak, N. M., \& Mahamod, Z. (2010). Understanding TESL pre-service teachers' teaching experiences and challenges via post-practicum reflection forms. Procedia-Social and Behavioral Sciences, 9, 722-728.

[21] Malaysia, K. P. T. (2006). Modul pembangunan kemahiran insaniah (soft skills) untuk institusi pengajian tinggi Malaysia. Serdang: Universiti Putra Malaysia, 1-52.

[22] Yen, T. S., \& Halili, S. H. (2015). Effective teaching of higher order thinking (HOT) in education. The Online Journal of Distance Education and e-Learning, 3(2), 41-47.

[23] Somprach, K., Popoonsak, P., \& Sombatteera, S. (2014). Soft skills development to enhance teachers' competencies in primary schools. Procedia-Social and Behavioral Sciences, 112, 842-846.

[24] Deveci, İ. (2019). A Review of Entrepreneurship Education in Teacher Education. Malaysian Journal of Learning and Instruction, 15(1), 105-148.

[25] Jusoh, M., Simun, M., \& Chong, S. C. (2011). Expectation gaps, job satisfaction, and organizational commitment of fresh graduates: Roles of graduates, higher learning institutions and employers. Education+ Training, 53(6), 515-530.

[26] Ispal, M., \& Jabor, M. (2014). Entrepreneurial Measurement Modelfor Teacher Education. Dipublikasikan dalam IOSR Journal of Research \& Method in Education (IOSR-JRME) Volume, 4, 21-25.

[27] Achor, E. E., \& Wilfred-Bonse, K. (2013). The need to integrate entrepreneurship education into science education teachers' curriculum in Nigeria. Journal of Science and Vocational Education (JSVE), 7.

[28] Ngang, T. K., \& Chan, T. C. (2015). The importance of ethics, moral and professional skills of novice teachers. Procedia-Social and Behavioral Sciences, 205, 8-12.

[29] Gobagoba, M., \& Moswela, B. (2014). Ethics education adherence by teacher trainees during teaching practice: A botswana perspective.

[30] Hadiyanto, H. (2011). THE DEVELOPMENT OF CORE 
COMPETENCIES AMONG ECONOMIC STUDENTS IN NATIONAL UNIVERSITY OF MALAYSIA (UKM) AND INDONESIA (UI) (Doctoral dissertation, Universiti Kebangsaan Malaysia).

[31] Orji, N. S. (2013). Assessment of employability skills development opportunities for senior secondary school chemistry students. Journal of Educational Research and Reviews, 1(2), 16-26.

[32] Ismail, I., Ahmad, A. R., \& Awang, M. M. (2017). A study of soft skills among polytechnic students. Open Journal of Social Sciences, 5(08), 295.
[33] Wu, Q. (2017). A Research into the Reform of College English Teaching Based on Cultivating" Critical Thinking Skills". In 2017 International Conference on Innovations in Economic Management and Social Science (IEMSS 2017). Atlantis Press.

[34] Yusoff, N. H. (2019). Integriti akademik dalam kalangan mahasiswa Universiti Kebangsaan Malaysia (UKM). Malaysian Journal of Society and Space, 15(4).

[35] Ginsburg, M. (2017). Teachers as Human Capital or Human Beings? USAID's Perspective on Teachers. Current Issues in Comparative Education, 20(1), 6-30. 